Arch. hist. jap. Vol. 18, n. 4 (January 1960).

P. $593-610$.

Anat. Labor. of Prof. H. SETO, Tohoku University, Sendai.

\title{
On the Innervation of the Snout and the Nasal Cavity of Cat in the Last Fetal Stage.
}

\author{
猫最終胎生期の鼻尖及び鼻腔の神経分布に就て。 \\ Tsuguo ASHINO 芦野扸夫.
}

(Received September 21, 1959.)

Since some years ago, the innervation, especially, the sensory innervation of various organs of man and some animals has been studied from the view-point of comparative histology and many interesting results have been obtained. As a link in this chain of studies, the present author has been also given the opportunity of studying the sensory nerve fibres and their terminations distributed in the snout, the nasal cavities and their surrounding parts of cat in the last stage of fetal life. The innervation of the snout of adult animals has been studied by many authors in the past. That of adult cat was the theme of study of ONO (1956) of this laboratory. The innervation of the nasal cavity, however, has been treated in a very few studies only, that of man having been studied by SETO and SADA (1944), by GOTO (1954) and SATO (1949) and that of adult cat by ONO (1956) alone, as far as I could ascertain. These studies, though few in number, have been carried out at this laboratory using the superb SETO's silver impregnation method, and are utterly reliable for their accuracy. Therefore, these works on human and adult animals' nose and snout furnished very valuable data for reference in my study.

The materials of my study, fixed in $10 \%$ neutral formol for a long time, were cut into $40 \mu$ frozen serial frontal sections, which were stained by SETO's impregnation and subjected to minute microscopic examination. The findings were studied in comparison with the results reported in the work of ONO cited above from embryological stand point and many valuable informations on the development of these organs and their nerve supply could be obtained, as reported in the following.

\section{Individual Findings.}

The cat's snout is already in nearly full formation in the last fetal stage, but it goes without saying that it is still far more infantile than that of adult cat. ABE of this laboratory has recently reported on his study on the development of the histology and the innervation of the snout of $4 \mathrm{th}-5$ th month cattle fetus. His results may be cited with interest in comparaeive study with my findings.

The snout of cat in the last fetal stage, unlike the snout of fetal cattle with sinus hairs growing on it here and there, is bare of any hair, as in adult cat and is clearly marked off from the haired skin around it. The epithelium of the snout is not a thick bladderlike one as that of the fetal cattle snout, but a far thinner 1013-rowed stratified flat epithelium, no horn plate being found yet in its surface 
layer (Figs. 1 and 2).

Epithelial sulci are found at rather regular intervals on the epithelial surface, where the epithelium projects far down into the propria and forms the so-called cristae limitantes, between which well-developed papillae grow out from the propria

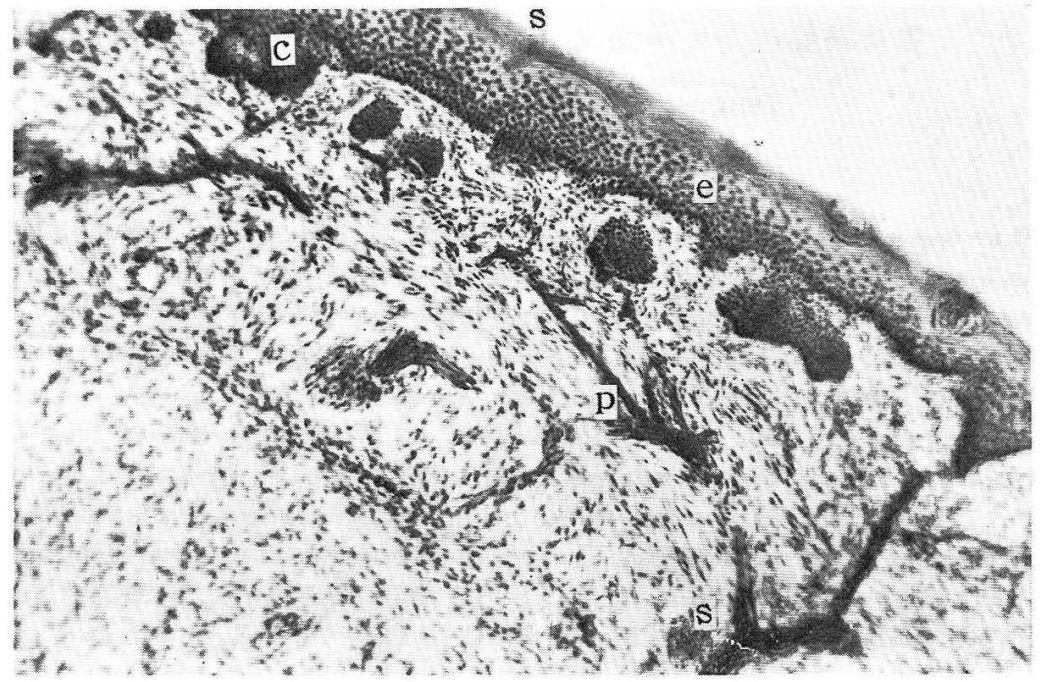

Fig. 1. A frontal section through the snout of a cat in the last fetal stage. $e$ nonhornified stratified flat epithelium, $s$ epithelial sulcus, $c$ crista limitans, $s$ submucosal nerve plexus, $p$ proprial nerve plexus. SETO's impregnation. Photo $\times 100$.

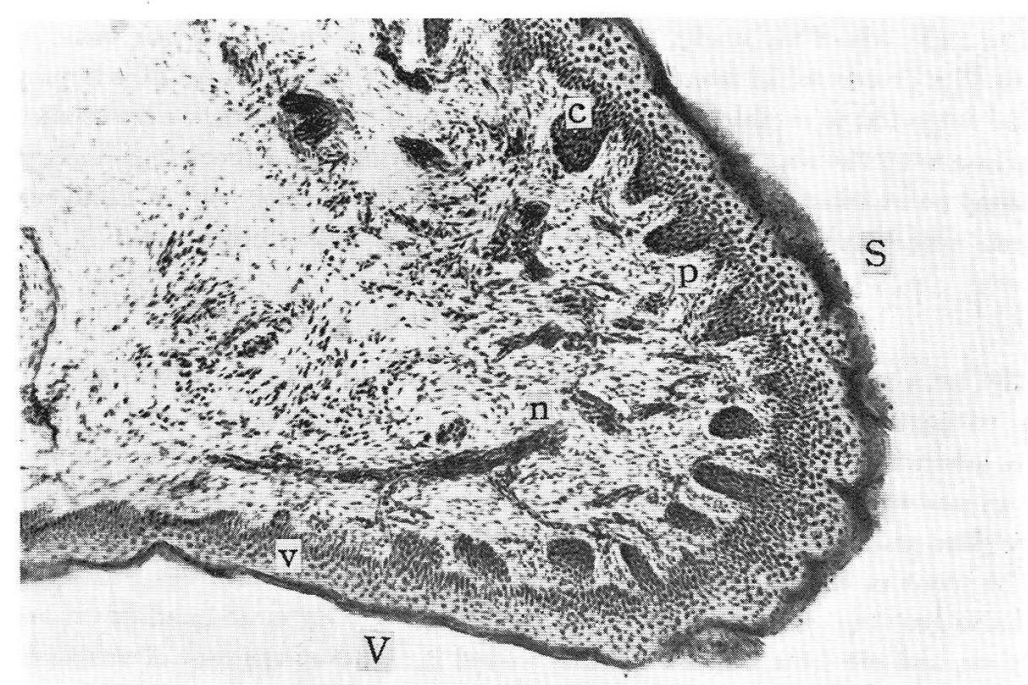

Fig. 2. A frontal section through the snout $(S)$ and the anterior part of the vestibulum nasi $(V)$ of a cat in the last fetal stage. $c$ crista limitans, $p$ papilla, $n$ proprial nerve plexus, $v$ vestibular epithelium having no horn-plate. Same staining. Photo $\times 100$. 
mucosae. The propria is a thin layer of Ionse connective tissue rich in small-sized fibrocytes. The submucosa beneath the propria is composed of a thick layer of connective tissue lamellae, composed of parallel arrangements of elongated fibrocytes and running in many directions, and contains neither snout glands nor sinus hair roots, as does that of cattle fetus (Figs. 1 and 2).

The snout of feline fetus, as that of many other mammals, is probably a special area embryologically originating in both the haired skin and the mucous membrane, but from the above microscopic findings, it may be concluded that this part in fetal cat is generally of mucous nature and thus most of the part originates in the mucous membrane.

The vestibulum nasi has a closed cartilaginous plate corresponding in form with its inner cavity. In frontal section, the nasal septal cartilage between the vestibules of both sides stands at the median line and its upper and lower edges extend neary symmetrically lateralwards, to form two semilunar arches. From a point somewhat below the apex of either arch protrudes inwards a cartilaginous process, to ond free in the nasal vestibule. The inside of this closed cartilage is covered by a mucous membrane (Fig. 3).

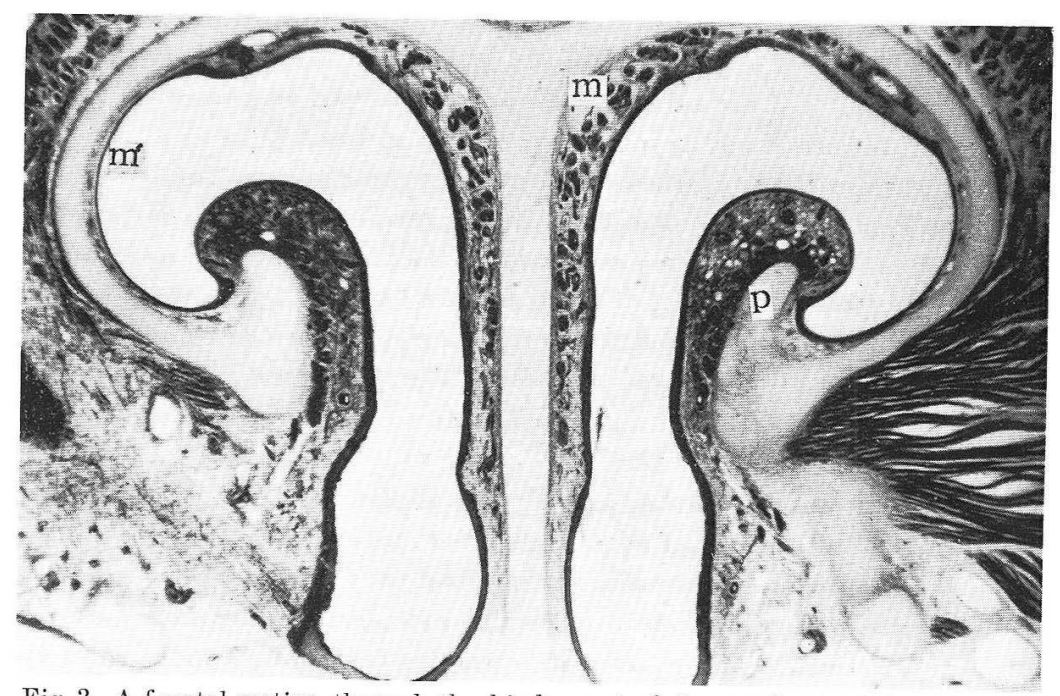

Fig. 3. A frontal section through the hinder part of the nasal vestibule of a cat in the last fetal stage. $p$ cartilaginous process from the side arch of the nasal septal catilage, $m$ thick mucous membrane containing nissal glands, $m$ ' thin mucous membrane devoid of nasal glands. Same staining. Photo $\times 24$.

The epithelium of the vestibulum nasi is of the same nature as that of the snout, but in thickness, is about half of the latter. No epithelial sulci are found here, but the formation of papillae from the propria mucosae is still observable in the foremost part of the vestibules. The papillae here, however, are smaller in size than those in the snout. The surface of the epithelium of the fore half of the vestibule of adult cat is covered by a thin horn plate, but in my fetal cat, this plate was not yet in formation (Fig. 2). The epithelium is the thinner, the thinner the subepithelial 
connective tissue layer beneath it. E. g., in the upper lateral part of the nasal vestibule, only a very thin 3-rowed stratified flat epithelium is seen (Fig. 3).

Both the propria mucosae and the submucosa of the vestibule being made of loose connective tissue rich in fibrocytes, their boundary is not distinctly defined, but since rather stout blood vessels are found in the submucosa only, the two layers can be distinguished in an approximate way.

In the nasal vestibule of cat's fetus, unlike in that of fetal cattle, nasal glands are not distributed everywhere, but appear only in its deep part (Fig. 3). Here too, the areas where the subepithelial connective tissue is thin are devoid of any glands.

In the zone where the vestibulum nasi passes over into the pars respiratoria of the nasal cavity, the stratified epithelium passes over for a while into a stratified cylindrical epithelium and then into the 3-4-rowed ciliated epithelium proper to the pars respiratoria. Nasal glands and venous plexus are in conspicuous formation in the subepithelial tissue of the pars respiratoria. In the spaces between the veins, however, no smooth muscle tissue could be found unlike in the human vestibule. Nasal glands were not found in the areas where the subepithelial tissue is thin, for example, in the mucous membrane at the base of the nasal cavity and over the upper lateral part of it.

The nerves coming into the snout of cat in the last fetal stage of course originate in $\mathrm{n}$. trigeminus and are already very well developed in this stage, forming quite powerful submucosal and proprial plexuses (Figs. 1 and 2).

The nerve fibres forming these plexuses comprise many medullated fibres of sensory nature and a few fine non-medullated vegetative fibres. The latter always become preterminal fibres and then end in STÖHR's terminal reticula, as demonstrated in all the past works in this laboratory, but in feline fetus, they are found only in the propria and are much smaller in number than those in the snout of bovine fetus provided with snout glands (ABE). The fine structure of these terminal reticula being quite identical with that reported in all the works from this laboratory, I will omit the details on it here.

The sensory fibres originating in the proprial plexus, as clearly illustrated in the report of ONO on the snout of adult cat but not specially mentioned by him, run into the papillae only on rare occasions in my fetal cat's snout too, but run in most cases toward the epithelial cristae, to end in branched terminations partly just beneath the epithelium, but more often after running further up into the epithelium, Thus, most of the sensory fibres end in intraepithelial branched terminations in the epithelial cristae.

These terminations, either subepithelial or intracristal, are of rather peculiar formation. They are mostly of complex type formed by rather thick stem fibres; their branch fibres most frequently show very perceptible change in size in their comparatively short and peculiarly windng courses and end in sharp points subepithelially or in the epithelial cristae.

In Figs. 4 and 5 , we see $2-3$ thick sensory fibres from the proprial plexus forming intraepithelial branched terminations in an epithelial crista. Their branch fibres undergo apparent change in size in their comparatively short and peculiarly winding courses and always end sharply in the crista. Intraepithelial branched 
Fig. 4. Intraepithelial branched termination found in a crista limitans (c) in the snout of a cat in the last fetal stage. Terminal fibres show conspicuous change in size in their winding short courses and end sharply. Same staining. $\times 320$.
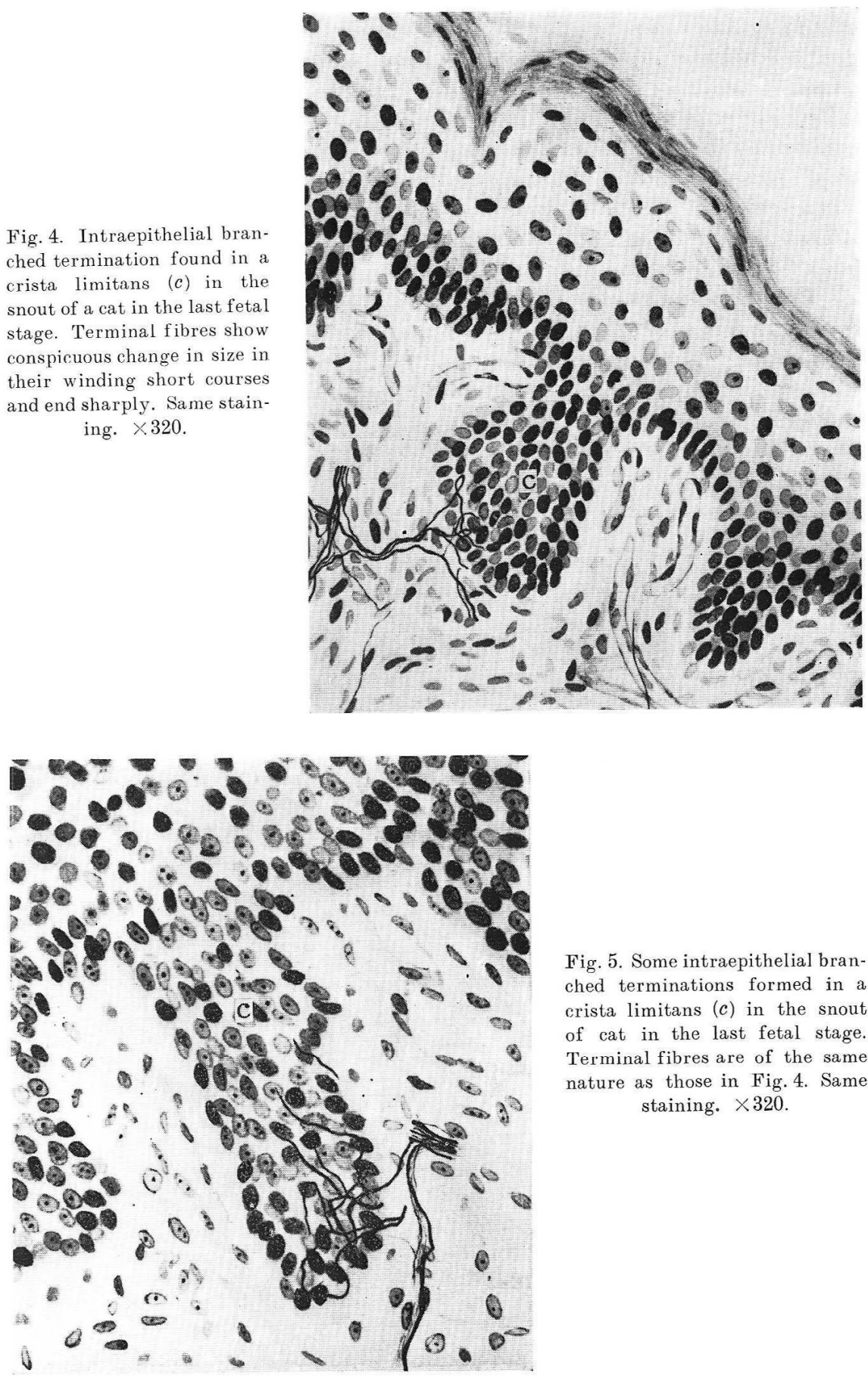

Fig. 5. Some intraepithelial branched terminations formed in a crista limitans (c) in the snout of cat in the last fetal stage. Terminal fibres are of the same nature as those in Fig. 4. Same staining. $\times 320$. 
terminations are found formed in all the cristae visible in Fig. 6, in forms very similar to those in Figs. 4 and 5. In Fig. 7 are shown many intracristal branched terminations of the characteristic formation described above.

Generally speaking, the branch fibres of the above intraepithelial branched terminations in the epithelial cristae end in the same cristae, but of ten enough, the branch fibres run further into the superficial layer of the epithelium outside the cristae. For example, in the intracristal branched termination seen in the right side of Fig. 8, 3 of the terminal fibres run beyond the boundary of the crista in the superficial layer of epithelium before ending.

ONO has found intraepithelial fibres observable in all the cristae in his feline snout, and it is of interest that I could make the same finding in my specimens of fetal feline snout, too.

Intraepithelial fibres running into the epithelium through the papillae are found also, but these are very limited in number. In my fetal specimens, these were always of unbranched type and never in the form of considerably complex branched terminations as found in the snout of adult cat.

Some points of rather deep interest are found upon studying in comparison the

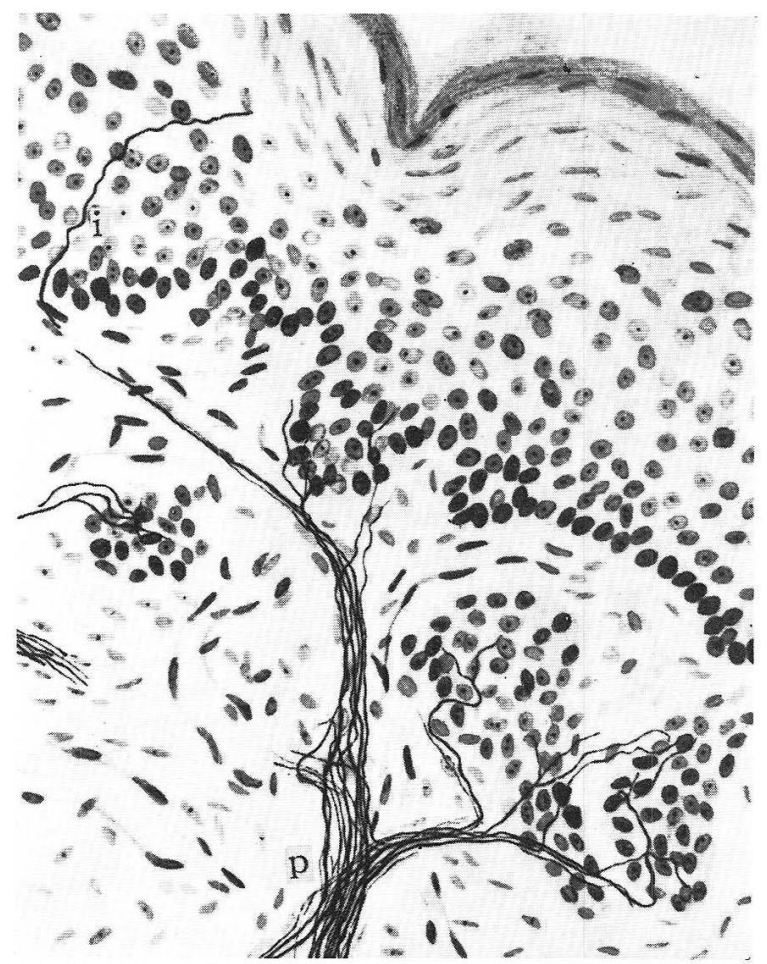

Fig. 6. Intraepithelial branched sensory terminations found formed in 4 cristae limitantes and an intraepithelial fiber $(i)$ reaching the superficial layer of the epithelium of the snout of a cat in the last fetal stage. $p$ proprial plexus. Same staining. $\times 320$. 
Fig. 7. Many intraepithelial sensory terminations composed of short terminal fibres rich in change in size formed in the same crista limitans in the snout of a cat in the last fetal stage. Same staining. $\times 320$.

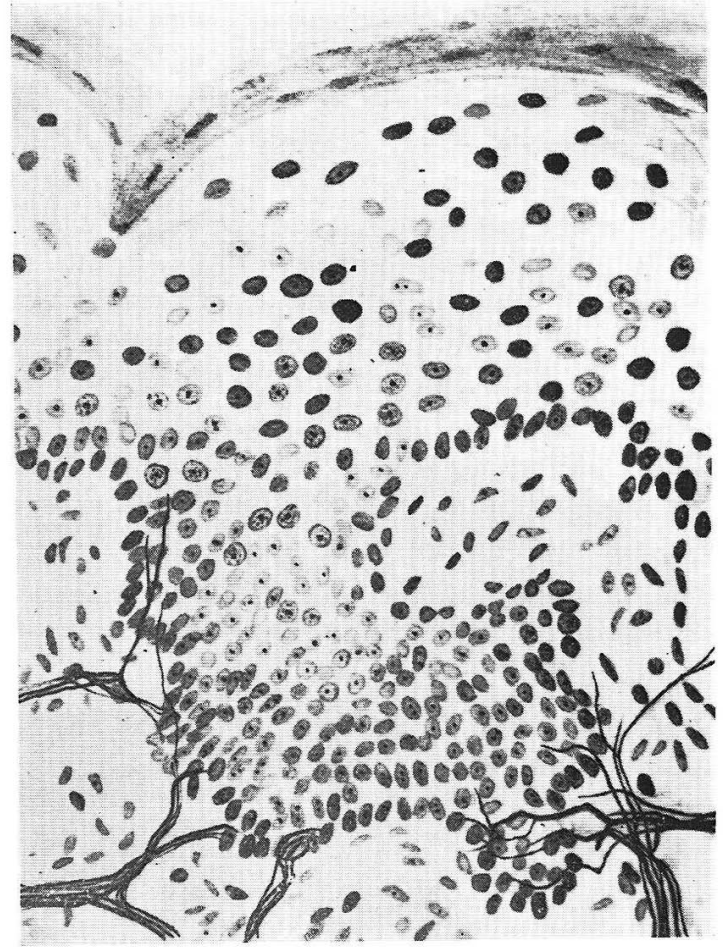

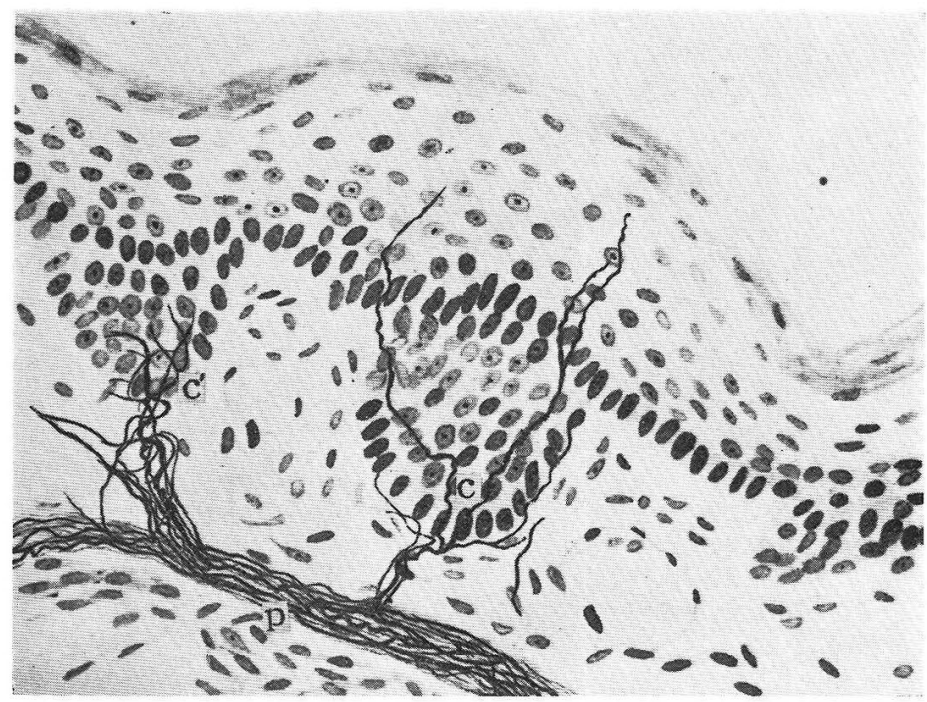

Fig. 8. An intracristal branched termination (c) with 3 of the terminal fibres running beyond the boundary of the crista in the superficial layer of the epithelium and another one $\left(c^{\prime}\right)$ composed of short terminal fibres limited in the crista found in the snout of a cat in the last fetal stage. $p$ proprial plexus. Same staining. $\times 320$. 
sensory nerve supply of the snouts of some animals. For example, branched terminations of very good development are found in the epithelial cristae of the snout of cat but not that of dog (I. SUGA and Y. SUGA). In the snouts of pig (MOMONO and TSUDA) and of fetal cattle (ABE), fibres running through the papillae into the epithelium are not absent either, but these are far poorer in development than those forming intraepithelial terminations in the cat's snout. In the snouts of pig and dog, simple end-bodies, especially, end-bulbs are often found besides branched terminations beneath the epithelium, but in the feline sout, no such corpuscular terminations were ever observable. It is a]so of interest that sensory terminations of all types are always morphologically different in these animals.

ONO, in his study, has found arteriovenous anastomoses of special construction in the submucosa of the snout and the nasal vestibululum of adult cat, and succeeded in shedding much light on the nerve supply to such anastomoses. In my fetal cat specimens too, I could make the same observation. As exemplified in Fig. 9, the arterio-venous anastomosis found in the submucosa of the snout of my fetal cat, quite like the HOYER-GROSSER's organ in the human palm of the hand (SETO), consists

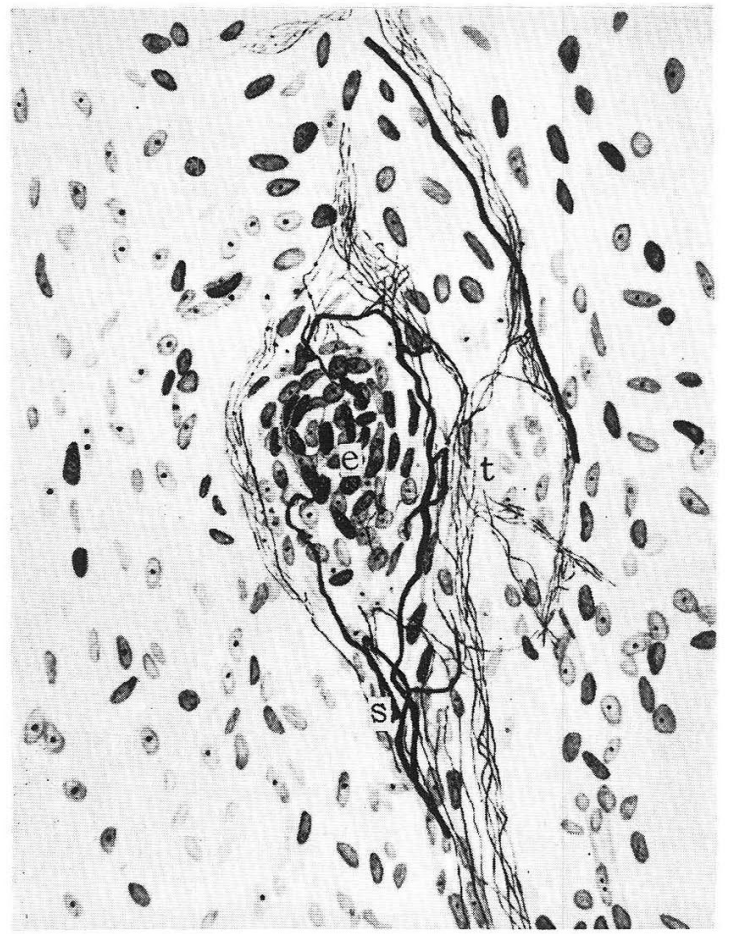

Fig. 9. Nerve supply of an arteriovenous anastomosis found in the submucosa of the snout of a cat in the last fetal stage. $t$ vegetative terminal reticulum, $s$ branched sensory termination composed of many thick branch fibres, $e$ epitheloid cell layer of the anastomosis. Details in the text. Same staining. $\times 320$. 
of a closed arrangement of 3-4 layers of spindle-form cells (epitheloid cells) and a connective-tissue adventitia outside it, the inside lumen being almost unvisibly small.

Around these anastomoses, terminal reticula representing the terminations of vegetative nerve fibres are in particularly conspicuous and powerful formation and partly penetrate into the epitheloid cell layer. A few thick sensory fibres too run into the adventitia of the anastomoses and end there in simple branched terminations. A part of their terminal fibres also run into the epitheloid cell layer and end in sharp points. Thus, the arterio-venous anastomoses of the snout of cat are fully provided with sensory terminations besides the vegetative terminal reticula, in its late fetal stage already. The existence of such sensory terminations here supposedly enables the arteriovenous anastomoses to play a reflex function of regulating the blood circulation in this part.

The vestibulum nasi of last-stage feline fetus is already well provided with sensory nerve fibres, especially so in its foremost part. In the foremost part adjoining the snout, many fibres and their termnations are found in powerful development, but their development fallls off as the deeper parts of the vestibule are reached and when we come to the vicinity of the bouudary between the vestibule and the respiratory part where the mucous membrane is covered by a thin cylindrical epithelium, the sensory fibres and their terminations become very poor affairs indeed. Also in the vestibular areas where the mucous membrane is very attenuated, especial$1 y$, in the upper lateral parts, the incoming sensory fibres are very ill developed.

The stratified flat epithelium extenbing from the snout into the vestibule is as yet considerably thick in the foremost part of the latter and the papillae growing into it from the propria here are well developed, so that in this part, the proprial plexus is also in good devclopment, though not so good as in the snout (Fig. 2).

The majority of the sensory fibres originating in this proprial plexus, as in the snout run into the epithelial cristae and a smaller number of them through the papillae into the epithelium over them, and end in intraepithelial terminations, mostly of branched type, often of rather complex formation. Their terminal fibres are also similar to those in the snout in that they show perceptible change in size in their peculiar looped courses. Not rarely, they reach the superficial layer of the epithelium before ending.

In Fig. 10 are shown some terminations of sensory fibres oriignating in the proprial plexus found in the mucous membrane of the nasal vestibule in the part adjoining the snout. The terminal fibres of these branched terminations in the two epithelial cristae here change their size rather frequently and run inter-as well as intra-epithelially as do such intraepithelial fibres commonly, some of them reaching the superficial layer of the epithelium, before ending sharply. In the papillae between the cristae, a simple branched termination may be seen. In Fig. 11 are illustrated some other intraepithelial terminations found in the same site as those in Fig. 10. At a glance, it seems as if one complex branched termination is shown here, but in reality the figure shows 2 unbranched and 2 simple branched terminations formed by 4 sensory stem fibres with intermingling terminal fibres. These terminal fibres do not show much change in size but some peculiar looping in their courses.

The epithelium in the part of the nasal vestibule adjoining to the haired skin 


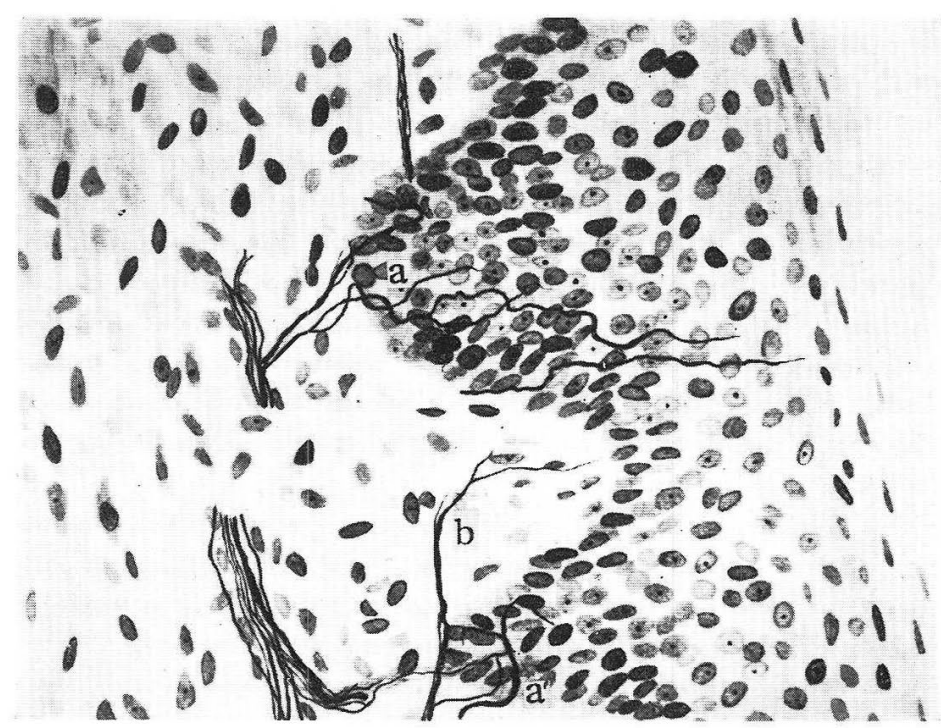

Fig. 10. Some sensory terminations formed in the mucous membrance of the nasal vestibule near the snout of a cat in the last fetal stage. $a$ and $a^{\prime}$ intraepithelial branched terminations formed in the epithelial cristae, some of the branch fibres reaching the superficial layer of the epithelium, $b$ simple branched sensory termination formed in the papilla between the two cristae. Same staining. $\times 320$.

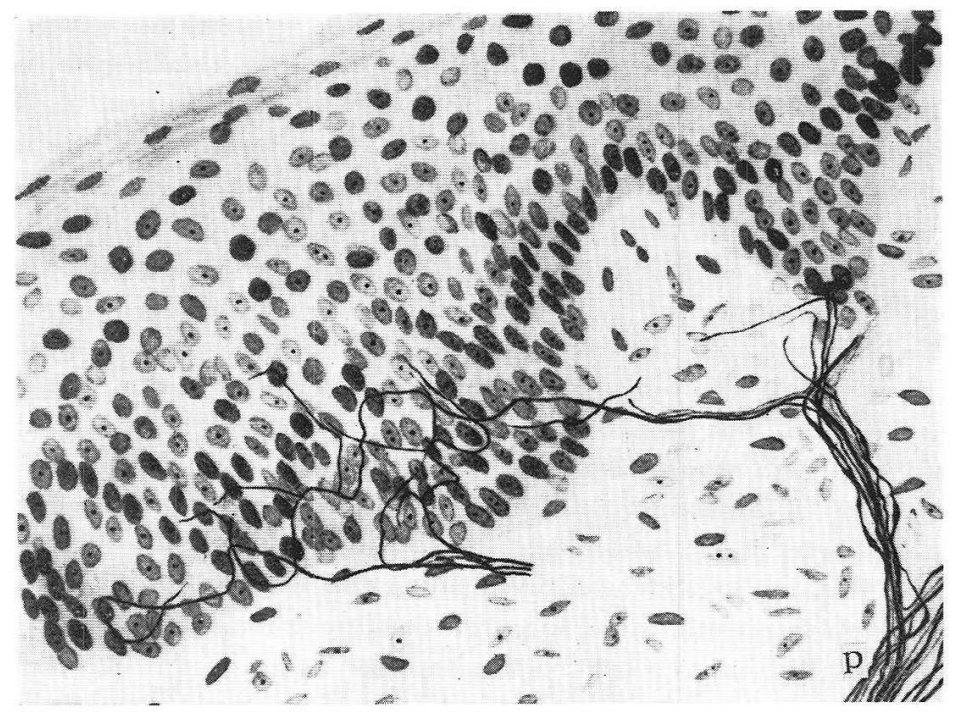

Fig. 11. 2 unbranched and 2 simple branched intraepithelial terminations with intermingling terminal fibres found in the same region of the nasal vestibule as that in Fig. 10. $p$ proprial plexus. Details in the text. Same staining. $\times 320$. 
is far thinner than that in the part near the snout and the papillae from the propria below are very ill developed or utterly non-existent in many places. Thus, the underside of the epithelium is nearly smooth and even. In this part, the proprial plexus is also poor in development, and consequently the sensory fibres are small in quantity and mostly end subepithelially in unbranched and simple branched terminations, but some of them run into the epithelium to end in intraepithelial fibres. Most of these intraepithelial terminations are of unbranched type, but a fewer of them are of simple branched type. In Fig. 12 is shown a bifurcated intraepithelial

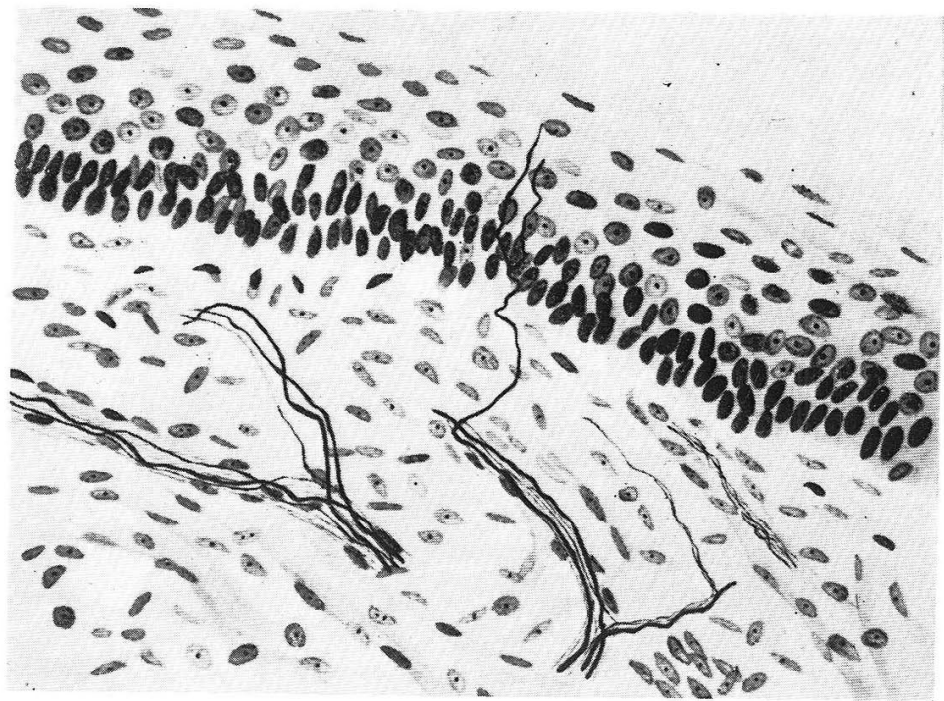

Fig. 12. A bifurcated intraepithclial and some unbranched subepithelial sensory terminations found in the mucous membrane of the nasal vestibule adjoining to the haired skin of a cat in the last fetal stage. Detals in the text. Same staining. $\times 320$.

termination found in the epithelium of this part. Its terminal fibres run right up into the epithelium without showing much change in size and end sharply near the surface layer of the epithelium.

As the deeper part of the vertibule is reached, the development of the proprial plexus gradually falls off, and accordingly, the number of sensory fibres also decreases abreast. Their terminations also become simpler in cotnstruction, those of unbranched type coming to predominate overwhelmingly, and most of them ending subepithelially, only a very few of them entering the epithelium.

The perichondrium of the cartilage in the wall of the vestibulum nasi of the last-stage fetus of cat contains a rather large number of sensory terminations, particularly richly in the foremost part of the nasal septum. These have been already found by ONO in adult cat and I could find them in my fetal cat specimen, too. These terminations always originate in thick sensory fibres and are of branched type. The terminal fibres generally show change in size and irregular running courses and usually end sharply but more rarely in blunt points. 
In Fig. 13 is shown a simple branched termination found in the perichondrium of the nasal septal cartilage at its foremost part. Its terminal fibres show marked change in size and finally taper off gradually into sharp points. In Fig. 14, a few simple branched terminations are found formed in the same region as that in Fig. 13.

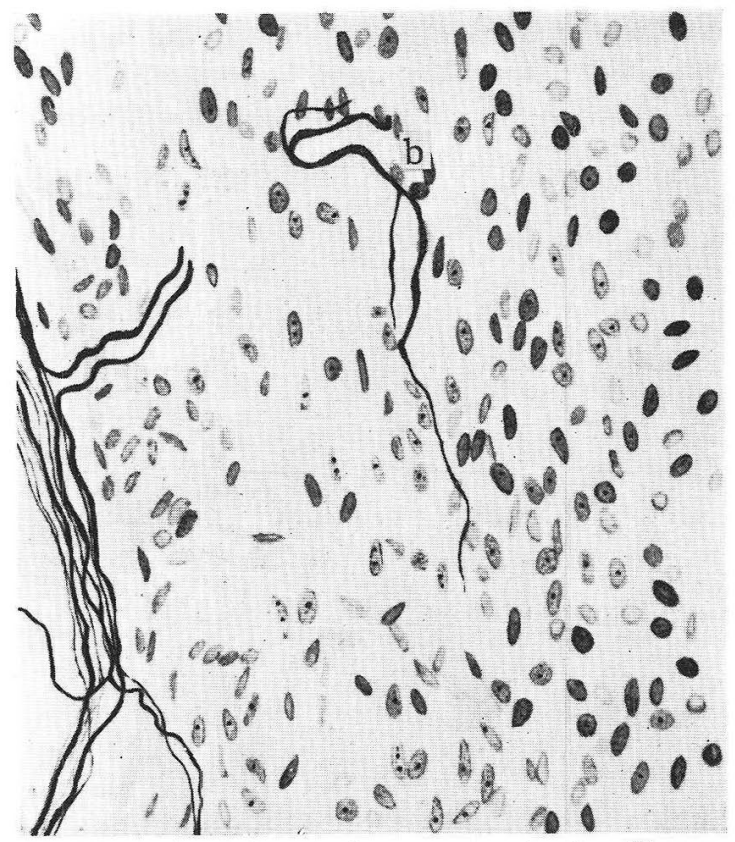

Fig. 13. A simple branched sensory termination (b) composed of terminal fibres rich in change in size found in the perichondrium of the nasal septal cartilage at its foremost part of a cat in the last fetal stage. Details in the text.

Same staining. $\times 320$.

The fibres are all considerably thick and their terminal fibres show change in size here and there; especially, the 4 terminal fibres of the termination (b) show very marked change in size and sharply or bluntly. In Fig. 15 is shown another termination with several branches found in the same region. Its terminal fibres are thin and show some change in size, run out short courses and end sharply.

According to SATO, while well-developed venous plexus is found in the pars respiratoria of the human nasal cavity and accordingly vegetative nerve plexus is in powerful formation, sensory fibres are very scarce there and their terminations are very simple, intraepithelial fibres being of very rare occurrence. Thus, the human pars sespiratoria is very poor in sensory nerve elements.

In adult cat (ONO), much more numerous sensory fibres are found in the pars respiratoria than in the case with man. The number of such fibres gradually decreases in the more hinder parts of the respiratory part. A part of these sensory fibres end subepithelially in unbranched and simple branched terminations, and intraepithelial terminations are not rare either. Thus, the respiratory part of the nasal 
Fig. 14. Some simple branched sensory terminations found in the same region as that in Fig. 13. $b$ branched sensory termination composed of 4 terminal fibres showing very marked change in size. Details in the text. Same staining. $\times 320$.
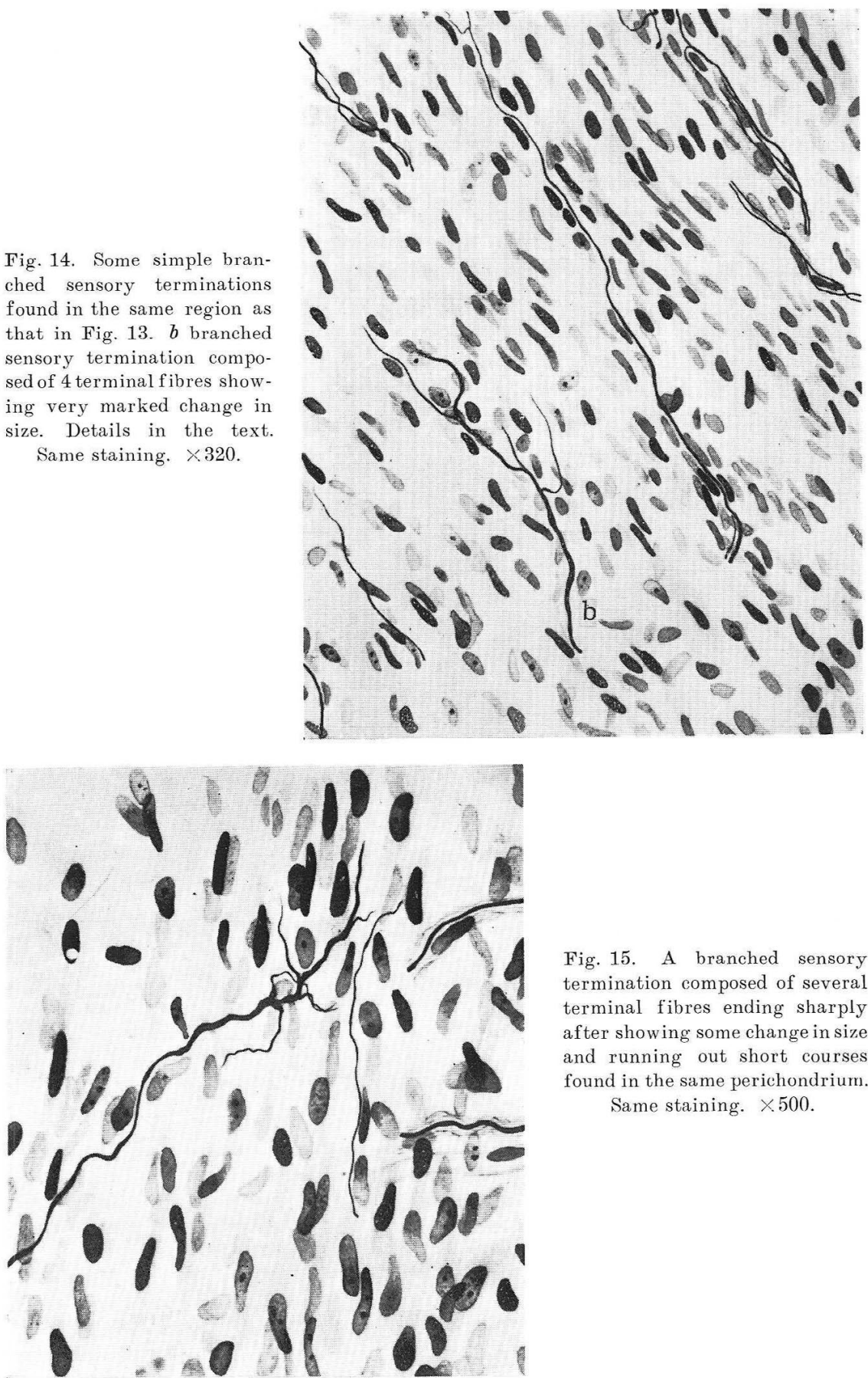

Fig. 15. A branched sensory termination composed of several terminal fibres ending sharply after showing some change in size and running out short courses found in the same perichondrium. Same staining. $\times 500$. 
cavity of cat is much better supplied with sensory fibres than that of man.

In my fetal cat specimens, submucosal plexus of fine vegetative fibres containing only a small number of sensory fibres was found in the areas of the pars respiratoria where the mucous membrane was well developed and the nasal glands too were proportionately developed. The vegetative fibres always form terminal reticula around the nasal glands and the venous plexus.

The sensory fibres in the pars respiratoria of the nasal cavity are fonnd also in fetal cat in the region not far from the vestibule, but farther backwards, their number gradually falls off. They end subepithelially in unbranched and simple branched terminations, but some of their terminal fibres run further up into the ciliated epithelium. Some fibres also directly run into the epithelium; these usually end as unbranched intraepithelial fibre. The terminal fibres of the sensory terminations in this part were found comparatively thin and to show little change in sire.

In Fig. 16 is shown a simple branched termination formed beneath the epithe-

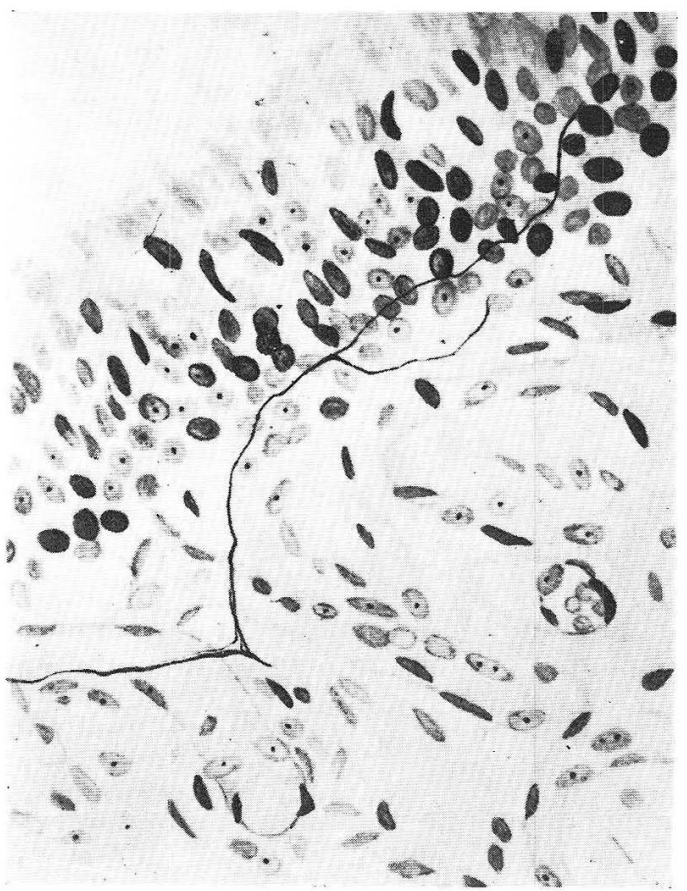

Fig. 16. A simple branched sensory termination formed beneath the ciliated epithelium of the pars respiratoria near the nasal vestibule of a cat in the last fetal stage. One of the terminal fibres showing not much change in size runs into the epithelium. Details in the text. Same staining. $\times 320$.

lium of the pars respiratoria near the vestibulum nasi. Its terminal fibres show not much change in size and no mentionable windings in their courses. One of them runs into the epithelium. In Fig. 17 is shown an unbranched intraepithelial fibre found 


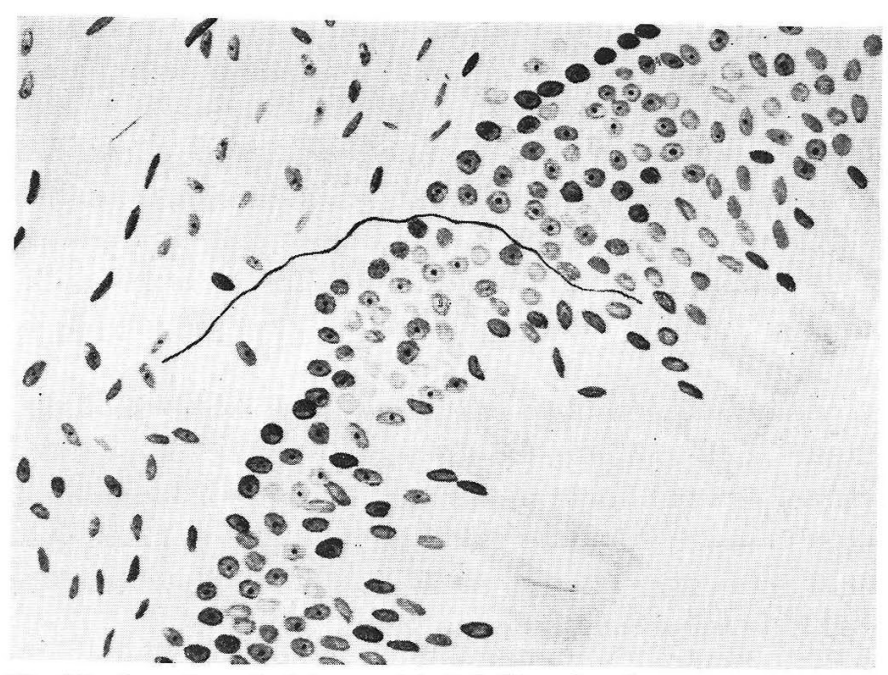

Fig. 17. An unbranched intraepithelial fibre found in the same region as that in Fig. 16. Details in the text. Same staining. $\times 320$.

in nearly the same place. Here, the thin fibre runs upward close to the surface before ending sharply.

\section{Summary.}

The snout is already in nearly full formation in the last fetal stage, but shows some infantility. Its mucous membrane is covered by a stratified flat epithelium far thinner than in fetal cattle (ABE) and has epithelial sulci on its surface. At the bottom of these sulci are formed distinct cristae limitantes. Between these cristae, papillae are found developed. In the submucosa, neither snout glands nor sinus hairs can be discovered.

The vestibula nasi have a catilaginous plate corresponding in shape to the inner vestibular moulding. The nasal septal cartilage stands on the median line and a semilunar cartilaginous arch extends on either side of it. A cartilaginous process juts out from a point somewhat lower than the mid-point of either arch. This closed cartilage is lined with a mucous membrane on its insidc, the epithelium is a stratified flat one far thinner than that of the snout and forms no epithelial sulci. Conspicuous papillae, however, are still in formation in the foremost part adjacent to the snout. Nasal glands are well developed in the areas where the mucous membrane is thick but absent in the areas where it is thin, in the deep parts of the vestibulum. The backmost part of the vestibnle is covered by a stratified cylindrical epithelium.

The pars respiratoria of the nasal cavity is nnder a ciliated epithelinm and nasal glands and venous plexus are in very good development in the submucosa beneath, but no smooth muscle fibres are found among the veins.

The snout of fetal cat of last stage is already richly supplied with sensory fibres. Very uumerous thick sensory fibres are found in the submucosal and the proprial plexus. Most of the sensory fibres run toward the epithelial cristae and a fewer 
toward the papillae. A small part of the former end subepithelially in branched terminations, but the larger part run further into the cristae to end similarly. These are already rather complexly constructed, their terminal fibres are thick and mostly show frequent change in size in their short and peculiar winding courses before ending sharply. Fibres that run up in rather long courses close to the superficial layer of the epithelium are not rare either. It is of interest that such terminations were found in all the cristae examined. The sensory terminations in the papillae are very scanty, and these few are nothing more complex than the simplest unbranched terminations.

Arterio-venous anastomoses were often found in the submucosa of the snout and the foremost part of the vestibulum nasi of my cat's fetus. These are not only very richly provided with terminations of vegetative fibres (STÖHR's terminal reticula), but also contain a comparatively large number of terminations of thick sensory fibres. Their terminal fibres show frequent change in size and often penetrate into the epitheloid cell layer before ending.

Sensory nerve fibres are found also rather numerous in the vestibulum nasi, and most of them are found in the parts adjoining the snout. As the deeper part of the vestibulum is reached, the number of sensory fibres decreases very rapidly, especially in the area where the mucous membrane is thin.

The mucous membrane covered by a thick papillae-containing epithelium in the part of the vestibulum nasi adjoining the snout also contains many sensory fibres, though not so many as in the snout. These usually enter the cristae to form intraepithelial branched terminations. The terminal fibres of these also show marked change in size and peculiar looped courses. A small number of unbranched and simple branched terminations are found in the papillae as well.

In the parts ot mucous membrane outside the areas provided with epitelial cristae and papillae in the vestibulum, the formation of proprial plexus is feeble, so that sensory fibres are also limited in number; these few sensory fibres end subepithelially in unbranched and simple branched terminations. On rare occasions, however, intraepithelial fibres, mostly of unbranched type, could be also detected.

The perichondrium of the cartilage in the surrounding wall of the vestibulum nasi, especially, that of the foremost part of the septum nasi, contains a rather large number of sensory terminations. These originate iu thick stem fibres and are mainly of branched type. Their terminal fibres show conspicuous change in size and irregular courses and end in sharp or blunt points.

The sensory fibres in the pars respiratoria of the nasal cavity of fetal cat are somewhat less scanty than in the human counterpart (SATO). Their number decreases gradually as we go from the fore to the back parts of the nasal cavity. Most of the sensory fibres here end in unbranched and simple branched terminations beneath the epithelium, but a small part of them form intraepithelial fibres. The terminal fibres here are comparatively thin and show not much change in size during their courses. 


\section{内 容自抄。}

最終期猫胎児の鼻尖む既に甚だ知覚線維に富む。即ち粘膜下膜及び固有膜神経 叢には甚だ多数の知覚線維が含まれる。乙の知覚線維の多くは強力に発達する上 皮稜に，そして極く少量は上皮稜間の乳頭内に向う。上皮稜に向う線維の 1 部は 上皮下に，然し大多数は上皮内に大って比較的複雑な分岐性終末に移行する。 そ の終末枝は太さの変化に富んだ太い線維加ら成り，短い特有な迁りを走り尖鋭状 に終る，尚中には上皮稜を越えて上皮表層に迄達する長い経過を走るあのあある。 乳頭内には僅少の専ら非分岐性終末の存在を見るに過ぎない.

鼻前庭にも知覚線維は可成り多量に発見されるが，その多くは鼻前庭の先端部 特に鼻尖に続く部に見られ，鼻前庭の後方に问うに從って知覚線維の量は急激に 減少する，特に狭い粘膜内に於て然りである。

鼻尖に続く鼻前庭の乳頭所有の厚い上皮で襒われる粘膜には鼻尖に於けるより は多少少ないが多くの知覚線維の進入を見，之等は専ら上皮稜内に入り分岐性終 末に終る。その終末枝も著明な太さの変化と迁曲走行とを示す。又乳頭内には僅 かの非分岐性及び単純性分岐性終末の形成を見る。

鼻前庭の中で乳頭を所有しない他の多くの粘膜に於ては固有膜神経叢の形成も 弱く, 從って知覚線維も少量, そして之等は上皮下に非分岐性及び単純性分岐性 終末に終る外，稀には非分岐性の上皮仢線維に移行する.

鼻前庭を包囲する軟骨特にその先端部方に於てはその軟骨膜の中に可なり多く の知覚終末が発見される。之は太い線維に由来する分岐性終末で, その終末枝は 著明な太さの変化と不規則な走行とを示し，その先端は尖鋭状に終る.

舅腔呼吸部には知覚線維は人の場合よりも稍々多量に存するが, その量は鼻腔 の前方から後方に進むに従って減少する，知覚線維は專ら上皮下に非分岐性及び 単純性分岐性終末に終るが，1部は上皮内線維に移行する。終末枝は余り太さの 変化を示さない細い線維で表わされる。

\section{References.}

Abe, R.; Histology and innervation of the nasal cavity with the snout in cattle embryo. Arch. hist. jap. 13 (1957). - Abe, Y.: Fine structure of nasal and oral cavities in dog. Tohoku J. exp. Med. 60 (1954). - Goto, M.: Histological study on innervation of pars mucosa of vestibulum nasi in human embryo. Tohoku J. exp. Med. 61 (1954). - Innervation of pars cutanea of vestibulum nasi and nasus externus in latter half of human embryonic life. Tohoku J. exp. Med. 61 (1954). - Momono, T. a. K. Tsuda: On innervation of snout of pig. Tohoku Igaku Zassi. 46 (1952). - Nozaki, K., I. Izumi, Sh. Niizuma a. M. Komatsu : On sensory innervation of vestibulum nasi in dog. Arch. hist. jap. 9 (1955). - Ono, Sh.: Histological study on the innervation of the snout and the nasal cavity with their surroundings in cat. Arch. hist. jap. 10 (1656). - Sato, T.: On innervation of pars respiratoria of cavum nasi in man. Tohoku Igaku Zassi. 40 (1949). - Seto, H.: Human sensibility. (Jap.) Igaku Shoin, Tokyo a. Osaka, 1957. - Seto, H. a. T. Sada: On the innervation of human vesti- 
bulum nasi with a few additional observations on the fine structure. Arch. hist. jap. 7 (1954). - Suga, I. a. Y. Suga : on the nerves especially on the sensory nerve terminations in the snout of dog. Tohoku Igaku Zassi. 45 (1951). 